\title{
Evaluation of the Factors that Promote Improved Experience and Better Outcomes of Older Adults in Intermediate Care Setting
}

\author{
Rona Blendell ${ }^{1}$ and Omorogieva Ojo ${ }^{2, *(1)}$ \\ 1 Lead Nurse, Joint Emergency Team, Greenwich Community Health Services, Oxleas NHS Foundation Trust, \\ Pinewood House, Dartford DA2 7WG, UK; rona.blendell@nhs.net \\ 2 School of Health Sciences, University of Greenwich, London SE9 2UG, UK \\ * Correspondence: o.ojo@greenwich.ac.uk; Tel.: +44-0-208-331-8626; Fax: +44-0-208-331-8060
}

Received: 19 December 2019; Accepted: 7 February 2020; Published: 8 February 2020

check for updates

\begin{abstract}
The aim of this article was to identify the main contributing factors to optimising improved experience and better outcomes for older adults participating in intermediate care setting. Background: Intermediate care is an integrated team intervention for patients experiencing an acute change in their function and well-being. Crisis intervention is one of several intermediate care pathways and provides a timely, person-centred, goal setting assessment to determine appropriate care and support for patients in the community. Method: This systematic review was conducted using key search terms and Boolean operators. A Critical Appraisal Skills Programme (CASP) tool was used to evaluate the studies and the data was extracted and synthesised systematically to develop themes relating to the research question. Results: Seven qualitative primary research studies and one mixed methods study were identified. The main themes were 'communicating with patients' and 'patient participation'. Results showed neither themes are parallel entities but co-dependent. Patient-centred approaches to communication by professionals encouraged active patient participation, in turn optimising patient outcomes. Conclusion: This review showed that patient participation in intermediate care requires professionals using advanced communication skills and taking time to actively listen to what is important to the patients. In addition, poor professional communication resulted in passive patient participation. Implications for future practice are discussed.
\end{abstract}

Keywords: intermediate care; older adults; crisis intervention; reablement; service improvement

\section{Introduction}

Intermediate care is a bed-based or home-based integrated service which is aimed at promoting recovery from illness, preventing unnecessary acute admissions to hospital and untimely admissions to long-term care, aiding timely discharge from hospital and maximising independent living [1,2]. In recognition of this, the National Service Framework (NSF) for older people in the UK [3] outlined eight national standards which aimed to reduce age discrimination and access to services, promote person centred care, and commission integrated services whilst treating people with respect and dignity according to individual needs.

The National Audit of Intermediate Care in England [4] outlined four service models to define intermediate care, including; bed-based intermediate care, home-based intermediate care, crisis response and reablement. The crisis response category is a community-based service which has a standard response time of four hours and an intervention period lasting up to $48 \mathrm{~h}$, while bed-based services are provided in acute and community settings with up to a six week intervention period [4]. In contrast, home-based intermediate care services are provided by multidisciplinary teams who 
are mainly health care professionals, who service users in their own homes for up to six weeks [4]. The reablement intermediate care services are also home-based services, but these are provided by multidisciplinary teams who are mostly social care professionals with interventions lasting up to six weeks $[4,5]$. The reablement intermediate care model is known as 'restorative care' in other countries and was historically commissioned by local authorities responsible for adult social care [6]. In addition, Rabiee and Glendinning [7] see reablement as a social care service which supports people to relearn practical skills and increase confidence by removing environmental barriers.

Home-based or bed-based intermediate care are two pathway options for patients referred to the crisis intervention team where the first author works. In particular, the bed-based intermediate care facility is a setting where patients can be transferred, from hospital or home. Both are integrated pathways with health and social care working closely together.

Thus, the team includes social workers, nurses, occupational therapists and physiotherapists with varying levels of experience and length of service. Referrals are triaged by a senior team member in the first instance and cases allocated thereafter with the team working towards a transdisciplinary model of care [8]. Innes et al. [8] revealed that transdisciplinary working is a unique method of bringing together a multidisciplinary professional skill set by completing competence-based training in other professional areas to increase a professional's range of practice in order to manage a variety of patient presentations.

The advantages of rapid care delivery in the community such as having better outcomes for patients, reductions in Accident and Emergency (A\&E) admissions and increased patient satisfaction in clinical crisis situations have been reported $[9,10]$. This is important in view of the increase in A\&E attendances [9]. Over the past 12 years the number of emergency admissions has increased by $42 \%$ in England which equates to 3.2\% average growth each year [11]. This is supported by data published by National Health Service (NHS) England which reported an increase of A\&E attendances in England during February 2019 of $7.3 \%$ on the same month in 2018 [12]. At a local level, statistics from the same report show that the A\&E facility in the first author's locality, had the third highest attendance compared to all other NHS London hospitals with 24,840 attendances in February 2019 alone.

Jones and Carroll [13] have also reported that the United Kingdom (UK) population is living longer with a significant number also living with complex needs, multi-morbidities and frailty. There is evidence that frail older people frequently require a different type and level of support than those people who are fitter and younger [14]. The NHS England [14] also suggests that frail older people are at increased risk of harm from hospital acquired infections, falls and pressure ulcers when being cared for in an acute setting with the risk of harm increasing with the length of stay.

However, a cornerstone of healthcare policy has been to reduce emergency admissions and it would appear that crisis intervention is a service which could be useful in reducing pressures in A\&E, hospitals and the care system. In this regard, National Institute for Health and Care Excellence (NICE) in UK [15] has recommended the commissioning of service by either health, social or jointly as part of an integrated service and should include nurses, therapists and social care staff.

Despite the advantages and challenges of intermediate care provisions, it would appear that not enough work has been done to explore the factors which contribute to optimizing improved patient experiences and better outcomes of intermediate care crisis interventions. Such approaches will no doubt help in identifying gaps in knowledge and skills of professionals and how this could translate into service improvement for professional practice. Therefore, the current literature review aims to identify key areas which may be a barrier or facilitate optimal patient experience and better clinical outcomes for older adults in intermediate care setting. It will also involve exploring the role of health care professionals who provide care for these patients. 


\section{Method}

\subsection{Search Strategy}

This was a systematic review which was conducted based on the PICO (Patient/problem-Older Adults; Intervention/exposure-Intermediate care; Comparison-Other clinical settings; Outcome-experiences and perceptions of users and healthcare professionals in intermediate care) model [16] and the Preferred Reporting Items for Systematic Reviews and Meta-Analyses (PRISMA) [17]. Several data bases in EBSCO host including Health Sciences Research Data bases which encompasses Academic Search Premier, Medline, Psychology and Behavioral Sciences Collection, PsychINFO, and CINAHL Plus were searched for relevant articles. The search terms and key words were 'older adults, older people, elderly, rehabilitation, reablement, independence, restorative, assessment, experience, goal setting, decision making, community, home-based, multi-disciplinary, multi-professional, collaboration and variants of these words and combined using Boolean operators ('and', 'or' and 'not') [18]. The search was repeated by the second author and the data extracted was also cross-checked by the second author. Based on the key terms used for the search, 47,059 articles were initially found on EBSCO host. The inclusion of other keywords using Boolean operators and limiters to refine the search brought the total articles from EBSCO host to 130. Additional searches were conducted using Google Scholar.

\subsection{Inclusion and Exclusion Criteria}

The search was limited to primary research articles produced between 2012 and October 2019. The reason for this is because of the UK National Health Service (NHS) reforms and policy $[9,15,19]$ which have changed significantly over this period with a clear shift in health and social care moving from parallel working towards integrated working. We included primary studies that included health care professionals or users aged over 65 years of intermediate care facilities as the participants [20,21]. In addition, studies published in English were included in the review.

Although the nature of the research question lends itself to qualitative study designs, there was no limitation in relation to qualitative or quantitative research design applied to the search strategy. While patients with different conditions such as cancer or dementia can be referred to the intermediate care for assessment, they are usually triaged at the point of referral and then accepted or declined after detailed discussion with the referrer. Therefore, cancer or dementia patients are not exclusion criteria for intermediate care, however, each patient is assessed holistically with the aim of ensuring the correct care pathway is identified. Studies not meeting these requirements were excluded from the review. Furthermore, studies involving patients undergoing neuro rehabilitation were also excluded as these patients have a very specific pathway and is a specialist patient group.

A PRISMA [17] flow diagram showing the findings of the systematic search is shown in Figure 1. 


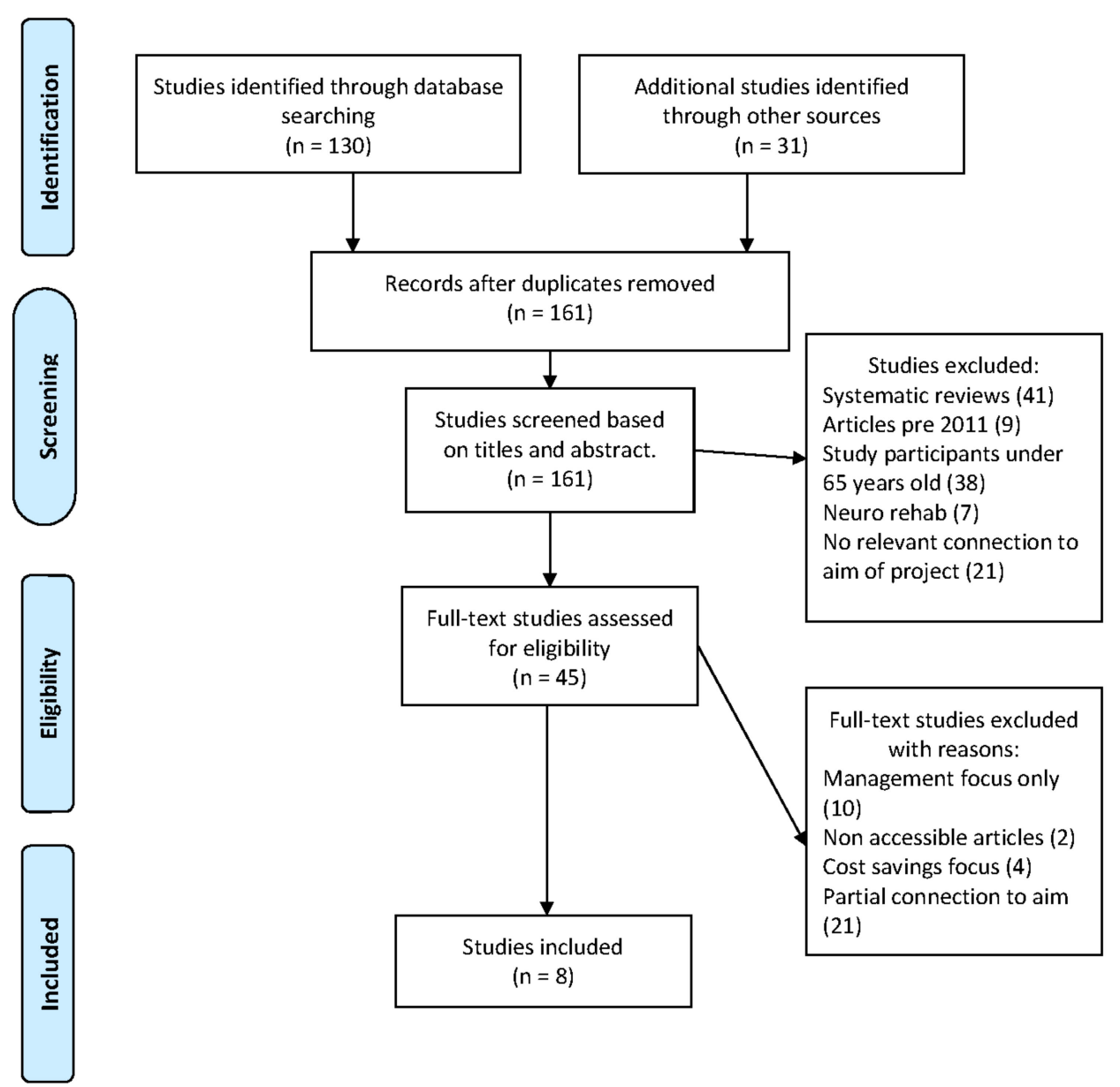

Figure 1. Preferred Reporting Items for Systematic Reviews and Meta-Analyses (PRISMA) (2009) Flow Diagram showing the findings of the systematic search.

\subsection{Data Extraction}

A data extraction table was used to extract data from the selected articles in order to identify emerging themes and patterns in a standardised way.

\subsection{Quality evaluation}

The qualitative Critical Appraisal Skills Programme (CASP) [22] checklist was used to evaluate the quality of the studies included. All the three sections of the checklist (Are the results valid? What are the results? Will results help locally?) were evaluated for each study and assessments were made using the information provided in the published paper only. Based on the evaluation, the articles included were found to be of good quality (Table 1).

\section{Results}

Eight primary research articles which contained information relevant to the research question were selected for this review (Table 2). Seven of the articles were based on qualitative research design and one article was of mixed methods.

While five of the studies [23-27] were conducted in Norway, two [28,29] were conducted in England, and one [30] in Sweden. 
Table 1. Evaluation of Quality of Studies included using the Critical Appraisal Skills Programme Checklist.

\begin{tabular}{|c|c|c|c|c|c|c|c|c|c|}
\hline Author & $\begin{array}{l}\text { Was There a Clear } \\
\text { Statement of the Aims } \\
\text { of the Research? }\end{array}$ & $\begin{array}{l}\text { Is a Qualitative } \\
\text { Methodology } \\
\text { Appropriate? }\end{array}$ & $\begin{array}{l}\text { Was the Research } \\
\text { Design Appropriate to } \\
\text { Address the Aims of } \\
\text { the Research? }\end{array}$ & $\begin{array}{c}\text { Was the Recruitment } \\
\text { Strategy Appropriate } \\
\text { to the Aims of the } \\
\text { Research? }\end{array}$ & $\begin{array}{l}\text { Was the Data } \\
\text { Collected in a Way } \\
\text { that Addressed the } \\
\text { Research Issue? }\end{array}$ & $\begin{array}{l}\text { Has the Relationship between } \\
\text { Researcher and Participants } \\
\text { been Adequately Considered? }\end{array}$ & $\begin{array}{l}\text { Have Ethical Issues } \\
\text { been Taken into } \\
\text { Consideration? }\end{array}$ & $\begin{array}{l}\text { Was the Data } \\
\text { Analysis Sufficiently } \\
\text { Rigorous? }\end{array}$ & $\begin{array}{l}\text { Is there a Clear } \\
\text { Statement of } \\
\text { Findings? }\end{array}$ \\
\hline $\begin{array}{l}\text { Birkeland et al. } \\
\quad[23]\end{array}$ & $\sqrt{ }$ & $\sqrt{ }$ & $\sqrt{ }$ & $\sqrt{ }$ & $\sqrt{ }$ & $\begin{array}{l}\mathrm{X} \\
\text { Leaders present in the group } \\
\text { may have affected discussion. }\end{array}$ & $\checkmark$ & $\sqrt{ }$ & $\sqrt{ }$ \\
\hline $\begin{array}{l}\text { Hjelle et al. } \\
\text { [24] }\end{array}$ & $\checkmark$ & $\sqrt{ }$ & $\checkmark$ & $\sqrt{ }$ & $\sqrt{ }$ & $\begin{array}{l}\mathrm{X} \\
\text { There may have been bias as } \\
\text { sample number was limited and } \\
\text { the study leader may have } \\
\text { 'cherry picked' participants who } \\
\text { experienced positive outcomes } \\
\text { therefore not a representative } \\
\text { sample. }\end{array}$ & $\checkmark$ & $\checkmark$ & $\checkmark$ \\
\hline $\begin{array}{l}\text { Hjelle et al. } \\
\text { [25] }\end{array}$ & $\sqrt{ }$ & $\sqrt{ }$ & $\sqrt{ }$ & $\sqrt{ }$ & $\sqrt{ }$ & $\checkmark$ & $\sqrt{ }$ & $\sqrt{ }$ & $\sqrt{ }$ \\
\hline $\begin{array}{c}\text { Jokstad et al. } \\
{[26]}\end{array}$ & $\checkmark$ & $\sqrt{ }$ & $\sqrt{ }$ & $\sqrt{ }$ & $\sqrt{ }$ & $\begin{array}{c}\mathrm{X} \\
\text { Project leaders known to } \\
\text { participants which may have } \\
\text { impacted on responses. } \\
\text { Conversely this may have made } \\
\text { for a more comfortable setting } \\
\text { for participants. } \\
\end{array}$ & $\checkmark$ & $\sqrt{ }$ & $\sqrt{ }$ \\
\hline Moe et al. [27] & $\sqrt{ }$ & $\sqrt{ }$ & $\sqrt{ }$ & $\sqrt{ }$ & $\sqrt{ }$ & $\sqrt{ }$ & $\sqrt{ }$ & $\sqrt{ }$ & $\sqrt{ }$ \\
\hline Rose et al. [28] & $\checkmark$ & * & $\checkmark$ & $\begin{array}{c}\checkmark \\
\text { Limited by small } \\
\text { sample size }\end{array}$ & $\sqrt{ }$ & $\sqrt{ }$ & $\checkmark$ & $\sqrt{ }$ & $\sqrt{ }$ \\
\hline $\begin{array}{c}\text { Wilde and } \\
\text { Glendinning } \\
\text { [29] }\end{array}$ & $\sqrt{ }$ & $\sqrt{ }$ & $\sqrt{ }$ & $\sqrt{ }$ & $\sqrt{ }$ & $\sqrt{ }$ & $\sqrt{ }$ & $\sqrt{ }$ & $\sqrt{ }$ \\
\hline $\begin{array}{c}\text { Randstrom } \\
\text { et al. [30] }\end{array}$ & $\sqrt{ }$ & $\sqrt{ }$ & $\sqrt{ }$ & $\sqrt{ }$ & $\sqrt{ }$ & $\checkmark$ & $\sqrt{ }$ & $\sqrt{ }$ & $\sqrt{ }$ \\
\hline
\end{tabular}


Table 2. Summary of the findings and implications for practice of the studies included.

\begin{tabular}{|c|c|c|c|c|c|}
\hline Author and Country & Aims and Objectives & Participants & Design & Findings & Implications for practice \\
\hline $\begin{array}{l}\text { Birkeland et al. [23] } \\
\text { Norway. }\end{array}$ & $\begin{array}{l}\text { To clarify how interdisciplinary } \\
\text { collaboration in reablement } \\
\text { worked in a Norwegian context. }\end{array}$ & $\begin{array}{c}33 \text { participants. } \\
9 \text { physiotherapists } \\
7 \text { occupational therapists } \\
9 \text { nurses } \\
4 \text { social educators } \\
3 \text { auxiliary nurses } \\
1 \text { social worker. }\end{array}$ & $\begin{array}{c}\text { Qualitative study } \\
\text { Focus groups of } 4-6 \text { people lasting 1-1.5 } \\
\mathrm{h} .\end{array}$ & $\begin{array}{l}\text { Interdisciplinary collaboration is dependent on } \\
\text { patients having the opportunity to identify their own } \\
\text { goals. } \\
\text { Staff considered interdisciplinary working enriching } \\
\text { and positive and reciprocal professional learning was } \\
\text { valued. } \\
\text { When organisational barriers are removed new } \\
\text { knowledge opens. } \\
\text { Interdisciplinary working dependent on motivation. }\end{array}$ & $\begin{array}{l}\text { Professional communication } \\
\text { skills - training. } \\
\text { Shared inclusive planning and } \\
\text { decision making. } \\
\text { Interdisciplinary collaboration can } \\
\text { improve professional performance } \\
\text { and satisfaction. } \\
\text { Time is important }\end{array}$ \\
\hline $\begin{array}{l}\text { Hjelle et al. [24] } \\
\text { Norway. }\end{array}$ & $\begin{array}{l}\text { To describe how older adults in } \\
\text { Norway experience } \\
\text { participation in reablement. }\end{array}$ & $\begin{array}{l}8 \text { participants. } \\
\quad 4 \text { men } \\
4 \text { women } \\
\text { Age range } 64-92 \text { years. }\end{array}$ & Qualitative descriptive study. & $\begin{array}{l}\text { Goals identified by patients are key to positive } \\
\text { outcomes. } \\
\text { Patient determination and responsibility are intrinsic } \\
\text { motivational factors and a driving force to achieving } \\
\text { goals set. } \\
\text { Team co-operation }\end{array}$ & $\begin{array}{l}\text { Patient centred goal setting } \\
\text { with professionals are key to } \\
\text { positive outcomes. } \\
\text { Teamwork. } \\
\text { Engaging the patient. }\end{array}$ \\
\hline $\begin{array}{l}\text { Hjelle et al. [25] } \\
\text { Norway. }\end{array}$ & $\begin{array}{l}\text { To explore and describe how an } \\
\text { integrated multidisciplinary } \\
\text { team in Norway experienced } \\
\text { participation in reablement. }\end{array}$ & $\begin{array}{c}2 \text { focus groups-all female. } \\
\text { Group } 1 . \\
6 \text { healthcare professionals with a } \\
\text { bachelor's degree; } \\
1 \text { physiotherapist } \\
2 \text { occupational therapists } \\
1 \text { social educator } \\
2 \text { nurses. } \\
\text { Group } 2 . \\
8 \text { home care personnel without } \\
\text { formal healthcare education; } \\
2 \text { auxiliary nurses } \\
6 \text { assistants. } \\
\end{array}$ & $\begin{array}{l}\text { Qualitative phenomenological } \\
\text { hermeneutic study. }\end{array}$ & $\begin{array}{l}\text { Different way of thinking. } \\
\text { Collaboration is motivating. } \\
\text { Patient goals are essential. } \\
\text { Patients were active recipients rather than passive } \\
\text { recipients. } \\
\text { Formal and informal meetings facilitate professional } \\
\text { collaboration and communication }\end{array}$ & $\begin{array}{l}\text { Inclusive person-centred goal } \\
\text { setting within a collaborative } \\
\text { integrated multidisciplinary team } \\
\text { can affect care delivery and } \\
\text { encourage active patient } \\
\text { engagement. } \\
\text { Communication skills training. }\end{array}$ \\
\hline $\begin{array}{l}\text { Jokstad et al. [26] } \\
\text { Norway. }\end{array}$ & $\begin{array}{l}\text { Explore healthcare } \\
\text { professionals' experiences of } \\
\text { user involvement in } \\
\text { reablement. }\end{array}$ & $\begin{array}{c}6 \text { nurse assistants } \\
6 \text { nurses } \\
3 \text { physiotherapists } \\
3 \text { occupational therapists } \\
\text { Focus Group } 1=7 \text { participants } \\
\text { Focus Group } 2=7 \text { participants } \\
\text { reduced to } 5 \text { due to to sickness } \\
\text { Focus Group } 3=6 \text { participants. }\end{array}$ & $\begin{array}{l}\text { Explorative descriptive qualitative } \\
\text { approach }\end{array}$ & $\begin{array}{l}\text { Challenging adjustment from 'doing for' to 'doing } \\
\text { with' users. } \\
\text { Modifications in attitudes and traditional practice. } \\
\text { Diverse ability to commit to what user involvement } \\
\text { requires. } \\
\text { Time invested during the initial phase contributes to } \\
\text { optimising outcomes of reablement. } \\
\begin{array}{c}\text { Values, attitudes and practices challenged due to } \\
\text { structural, cultural and personal factors. }\end{array}\end{array}$ & $\begin{array}{l}\text { Protected venues for } \\
\text { interdisciplinary meetings key to } \\
\text { develoloing and maintaining } \\
\text { interdisciplinary competences. } \\
\text { Flexibility and professional } \\
\text { adjustment promote the ideal of } \\
\text { transforming 'user involvement } \\
\text { into practice'. } \\
\text { Time invested with patients in the } \\
\text { initial phase of reablement pathway } \\
\text { contribute to encouraging patient } \\
\text { involvement. }\end{array}$ \\
\hline
\end{tabular}


Table 2. Cont.

\begin{tabular}{|c|c|c|c|c|c|}
\hline Author and Country & Aims and Objectives & Participants & Design & Findings & Implications for practice \\
\hline $\begin{array}{l}\text { Moe et al. [27] } \\
\text { Norway. }\end{array}$ & $\begin{array}{l}\text { To gain knowledge about } \\
\text { conversation processes and } \\
\text { patient influence in formulating } \\
\text { patients' goals }\end{array}$ & $\begin{array}{c}8 \text { patients cases chosen. } \\
5 \text { women } \\
3 \text { men } \\
\text { Ages } 67-90 \text { years old. } \\
\text { Mean age }=80 \text { years } \\
\text { All patients lived in their own private } \\
\text { homes. } \\
\text { Professional team = occupational } \\
\text { therapist, physiotherapist, nurse and } \\
\text { care workers. } \\
\end{array}$ & $\begin{array}{l}\text { Qualitative naturalistic enquiry } \\
\text { based on purposive sampling. }\end{array}$ & 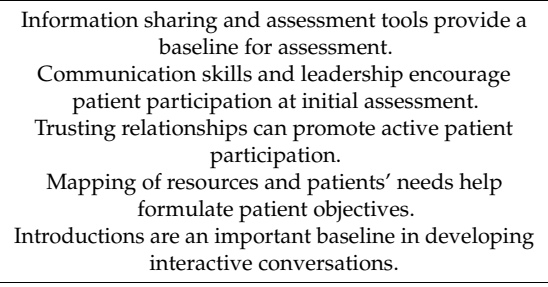 & $\begin{array}{l}\text { Interactive and inclusive goal } \\
\text { setting with patients is key. } \\
\text { Competence in professional's } \\
\text { communication skills to encourage } \\
\text { patient understanding and } \\
\text { engagement. } \\
\text { Information sharing. }\end{array}$ \\
\hline $\begin{array}{l}\text { Rose et al. [28] } \\
\text { England. }\end{array}$ & $\begin{array}{l}\text { To assess the extent of shared } \\
\text { decision making within goal } \\
\text { setting meetings and explore } \\
\text { patient reported factors that } \\
\text { influenced their participation to } \\
\text { shared decision making about } \\
\text { their goals. }\end{array}$ & $\begin{array}{c}\text { Patients with a frailty syndrome } \\
\text { defined by BGS eligible for Phase } 1 \\
\text { (P1) } \\
40 \text { participants selected-20 patients } \\
\text { from each setting } \\
\text { (community/inpatient) } \\
13 \text { rehab assistants, } 6 \\
\text { physiotherapists and } 5 \text { occupational } \\
\text { therapists approached for consent to } \\
\text { participate in the study, } 3 \text { rehab } \\
\text { assistants declined. }\end{array}$ & $\begin{array}{l}\text { Mixed methods approach in } 2 \text { phases. } \\
\text { Phase } 1 \text { Questionnaire. } \\
\text { Phase } 2 \\
\text { Qualitative data collected through semi } \\
\text { structured interviews. }\end{array}$ & $\begin{array}{l}\text { Patient participation increased if staff appeared to } \\
\text { listen during interactions. } \\
\text { With information patients are more likely to want to } \\
\text { engage in decision making/goal setting. }\end{array}$ & $\begin{array}{l}\text { Information sharing. } \\
\text { Professionals complex } \\
\text { communication skills. } \\
\text { Active listening. } \\
\text { Inclusive decision making. } \\
\text { What is important to the patient. }\end{array}$ \\
\hline $\begin{array}{c}\text { Wilde and Glendinning } \\
\text { [29] } \\
\text { England. }\end{array}$ & $\begin{array}{l}\text { To identify the perceptions and } \\
\text { experiences of users of } \\
\text { reablement services. }\end{array}$ & $\begin{array}{c}34 \text { service users and } 10 \text { carers from } 5 \\
\text { established reablement services in } \\
\text { England. }\end{array}$ & $\begin{array}{l}\text { Qualitative study using data collected in } \\
\text { the course of a larger mixed methods } \\
\text { study. }\end{array}$ & $\begin{array}{l}\text { Explanation of service and intermittent reminders } \\
\text { during intervention is critically important. } \\
\text { Lack of patient knowledge and understanding of } \\
\text { intervention has a detrimental effect on engagement. } \\
\text { Understanding patient and carers priorities are central } \\
\text { to successful reablement outcomes. } \\
\text { Demotivation and frustration can occur when patients } \\
\text { own goals are not addressed. } \\
\text { Communication and understanding vital to outcome } \\
\text { of intervention. }\end{array}$ & $\begin{array}{l}\text { Patient centred goal planning is an } \\
\text { inclusive process. } \\
\text { Clear communication in different } \\
\text { formats shared at intervals of } \\
\text { intervention can reinforce and } \\
\text { re-engage patients. } \\
\text { Including and engaging carers in } \\
\text { the reablement goal setting phase } \\
\text { and throughout the process can } \\
\text { improve outcomes. } \\
\text { Communication skills training. }\end{array}$ \\
\hline $\begin{array}{l}\text { Randstrom et al. [30] } \\
\text { Sweden. }\end{array}$ & $\begin{array}{l}\text { To explore multidisciplinary } \\
\text { teams' experiences of home } \\
\text { rehabilitation for older people. }\end{array}$ & $\begin{array}{c}5 \text { focus groups covering } 7 \text { different } \\
\text { professions. } \\
28 \text { participants in total. } \\
6 \text { physiotherapists } \\
3 \text { occupational therapists } \\
5 \text { district nurses } \\
5 \text { nursing assistants } \\
1 \text { home help } \\
3 \text { home help needs assessment } \\
\text { officers } \\
5 \text { home help officers in charge }\end{array}$ & Descriptive qualitative study. & $\begin{array}{c}\text { Team bases promote team communication } \\
\text { Team supervision supports a restorative approach. } \\
\text { 'Hands off' patient support } \\
\text { promoted patient's participation } \\
\text { Planning and flexibility were considered significant to } \\
\text { supporting person centred care. } \\
\text { Person centred approaches, interpersonal } \\
\text { relationships and emotional support facilitates } \\
\text { participation during intervention. } \\
\text { Willingness and positive attitudes to understand } \\
\text { colleague's contribution was conducive to supporting } \\
\text { a patient independence. }\end{array}$ & $\begin{array}{l}\text { Episodes of patient care should } \\
\text { come from an 'emerged whole } \\
\text { team performance'. } \\
\text { Communication skills training. }\end{array}$ \\
\hline
\end{tabular}




\subsection{Themes}

The two emerging themes were 'communicating with patients' and 'patient participation' although both themes are closely linked.

\subsection{Communicating with Patients}

All eight articles discussed communication to varying degrees. Hjelle et al. [24] outlined the importance of patients' understanding of an intermediate care intervention while others [27-29] observed that communication involves discussing patients' preferences and reported that actively listening to patients led to an increase in patient engagement and participation. In addition, poor communication between professionals and patients have a negative impact on patient assessments and outcomes as patients are not able to understand what could be achieved during intermediate care interventions [28]. Jokstad et al. [26] agrees and suggests that professionals using open ended questions, showing an understanding of patients' wishes demonstrated to the patient that their voice had been heard.

\subsection{Patient Participation}

Three studies [27-29] reported that 'active listening' by professionals led to understanding what was important to the patient and encouraged patient participation and engagement when goal setting. Hjelle et al. [24] noted that patient participation increased when goals were identified by patients rather than set by a professional. Verbal and non-verbal communication were discussed by three studies [27-29] and written information was advocated as a method of communication to encourage patients' understanding and engagement from the onset of rehabilitation. The importance of time needed when communicating with patients to optimise outcomes was also highlighted $[23,25,26]$. Rose et al. [28] and Moe et al. [27] revealed that patient participation was optimised when patient felt they were listened to.

\section{Discussion}

This review examined the contributing factors to optimising improved experience and better outcomes for older adults in intermediate care setting. Seven qualitative design studies and one study with a mixed methods approach met the inclusion criteria. Data extraction identified two main themes: Communicating with patients and Patient participation in the intermediate care pathway. Both themes are discussed below.

Communication was a common theme running through all eight research studies, however, the importance and method of communication varied in detail. According to Ali [31], communication is an exchange of information which involves the use of speech, body language or written information. In addition, Moe et al. [27] noted that several communication techniques such as asking open questions, active listening and summarising conversation motivated patient participation. The Nursing and Midwifery Council in UK [32] recommends that professionals should communicate clearly with patients using assistance when needed and consider non-verbal and verbal methods to support patient understanding. Verbal and non-verbal communication are central to patient assessment [33]. Communication is practiced by every health care professional, therefore, the importance of recognising different approaches is vital to optimising interactions generally.

In the current review, Moe et al. [27] observed that patient to professional communication relating to rehabilitation is often aimed at the patient identifying their own goals rather than healthcare professionals planning interventions. In addition, interdisciplinary communication and collaboration is dependent on patient set goals as it keeps the patient central to the intervention [23-25,27,30].

It has been suggested that professional collaboration was an extrinsic motivational factor that encouraged patients to achieve their goals and focus on what is important to the patient [24]. Patients 
can feel demotivated when they lack knowledge or feel they have not been listened to and this could limit engagement in communication [29].

All eight studies showed that improved outcomes of intermediate care interventions were optimised when patients identified their own goals during initial meetings. There is evidence that the provision of information at the outset using both verbal and non-verbal formats can prepare patients and increase patients' participation [28]. Therefore, communication strategies such as allowing time during the initial assessment with the patient is important and encourages patient participation [26,34]. In contrast, limiting assessment time can be a barrier to patients' understanding and motivation [29]. Thus, an optimal degree of patient participation can only be achieved when time is not limited which allows knowledge to be shared and relationships to develop based on mutual respect and trust [35].

In addition, patients who have participated in defining their own rehabilitation goals can facilitate professional teamwork and promote patient centered assessments [23]. On the other hand, professional encouragement during communication and professionals displaying active listening can lead to patient participation and retention of content of conversation $[24,27,28]$.

It has also been revealed that patients in crisis, anxious or experiencing acute ill health may have impaired ability to engage in communicating with professionals as the ability to absorb information and awareness may be impaired temporarily [29]. This is relevant as patients in clinical practice who are referred to the intermediate care service are generally experiencing an acute episode of poor health and in crisis. The importance of professional competency relating to communication skills and time taken especially during the initial assessment is therefore crucial to optimise patient communication and participation.

It has been reported that the use of written communication as a reminder of the discussion with patients reduces anxiety and facilitates participation [28]. Awareness of the patient's literacy abilities and language should also be taken into account. This aligns with NICE [36] guidelines which recommends that information should be considered in appropriate formats such as pictures, symbols, large print, braille and different languages to support the needs of patients. Supported communication may include the use of translators, information presented in different formats or portable Internet Technology. For example, Hjelle et al. [24] used the Canadian Occupational Performance Measure (COPM) tool to identify and plan rehabilitation goals with the patients which helped guide both patient and professionals throughout the intervention, encouraging patient motivation and promoting participation.

\section{Study Limitations}

The exclusion of studies not published in the English language is a limitation of this review as this may affect the spread of the studies selected. Furthermore, only two studies were conducted in England, five in Norway and one in Sweden and there may be variations in the approaches to the studies. It is also possible that the inclusion of more studies could have added wider dimension to results and findings.

\section{Conclusions}

The aim of the literature review was to identify the main factors which contribute to optimising improved experience and better outcomes for older adults participating in an intermediate care pathway. The authors identified seven qualitative primary research papers and one mixed method study. Two themes emerged and these were 'communicating with patients' and 'patient participation' in the intermediate care pathway.

This review found that the use of verbal and non-verbal communication skills, and advanced communication skills such as active listening skills, allowing time for patients to share thoughts, feelings, fears and anxieties by professionals were contributing factors to optimising improved patients' experience and better outcomes including patients' participation. 
Author Contributions: R.B. conceptualised the topic, conducted the initial search and wrote the initial draft; O.O. supervised the manuscript, repeated the searches, reviewed and revised the manuscript. All authors have read and agreed to the published version of the manuscript.

Funding: This research received no external funding

Conflicts of Interest: The authors declare no conflict of interest.

\section{References}

1. National Institute for Health and Care Excellence. Intermediate Care Including Reablement. Quality Standard 173. 2018. Available online: https://www.nice.org.uk/guidance/qs173/resources/intermediate-careincluding-reablement-pdf-75545659227589 (accessed on 18 March 2019).

2. Brooks, N. Intermediate care rapid assessment support service: An evaluation. Br. J. Commun. Nurs. 2002, 7,623-633. [CrossRef] [PubMed]

3. Department of Health. National Service Framework for Older People. 2001. Available online: https: //www.gov.uk/government/publications/quality-standards-for-care-services-for-older-people (accessed on 3 March 2019).

4. National Audit of Intermediate Care Summary Report. Assessing Progress in Services for Older People Aimed at Maximizing Independence and Reducing Use of Hospitals. 2015. Available online: https://static1.squarespace.com/static/58d8d0ffe4fcb5ad94cde63e/t/58f08efae3df28353c5563f3/ 1492160300426/naic-report-2015.pdf (accessed on 13 March 2019).

5. Ebrahimi, V. Reablement: Shifting Minds. In Reablement Services in Health and Social Care; Ebrahimi, V.A., Chapman, H.M., Eds.; Palgrave: London, UK, 2018; pp. 21-24.

6. Tuntland, H.; Aaslund, M.K.; Espehaug, B.; Forland, O.; Kjeken, I. Reablement in Community-Dwelling Older Adults: A Randomized Controlled Trial. BMC Geriatr. 2015, 15, 145. Available online: https: //bmcgeriatr.biomedcentral.com/articles/10.1186/s12877-015-0142-9 (accessed on 2 March 2019). [CrossRef] [PubMed]

7. Rabiee, P.; Glendinning, C. Organisation and delivery of home care re-ablement: What makes a difference? Health Soc. Care Commun. 2011, 19, 495-503. [CrossRef] [PubMed]

8. Innes, K.; Crawford, K.; Jones, T.; Blight, R.; Trenham, C.; Williams, A.; Griffiths, D.; Morphet, J. Transdisciplinary care in the emergency department: A qualitative analysis. Int. Emerg. Nurs. 2016, 25, 27-31. [CrossRef] [PubMed]

9. Department of Health. Five Year Forward View. 2014. Available online: https://www.england.nhs.uk/wpcontent/uploads/2014/10/5yfv-web.pdf (accessed on 23 January 2019).

10. Oliver, D.; Foot, C.; Humphries, R. Making Our Health and Care Systems Fit for and Ageing Population. 2014. Available online: https://www.kingsfund.org.uk/sites/default/files/field/field_publication_file/makinghealth-care-systems-fit-ageing-population-oliver-foot-humphries-mar14.pdf (accessed on 3 January 2019).

11. Steventon, A.; Deeny, S.; Friebel, R.; Gardner, T.; Thorlby, R. Briefing: Emergency Hospital Admissions in England: Which May be Avoidable and How? The Health Foundation: London, UK, 2018; Available online: https://www.health.org.uk/publications/emergency-hospital-admissions-in-england-which-maybe-avoidable-and-how (accessed on 24 March 2019).

12. National Health Service (NHS) England. A \& E Attendances and Emergency Admissions February 2019 Statistical Commentary. 2019. Available online: https://www.england.nhs.uk/statistics/wp-content/uploads/ sites/2/2019/03/Statistical-commentary-Feb-2019.pdf (accessed on 2 April 2019).

13. Jones, J.; Carroll, A. Hospital admission avoidance through the introduction of a virtual ward. Br. J. Commun. Nurs. 2014, 19, 330-334. [CrossRef] [PubMed]

14. National Health Service (NHS) England. Safe, Compassionate Care for Frail Older People Using an Integrated Care pathway: Practical Guidance for Commissioners, Providers and Nursing, Medical and Allied Health Professional Leaders. 2014. Available online: https:/www.england.nhs.uk/wp-content/uploads/2014/02/safecomp-care.pdf (accessed on 12 January 2019). 
15. National Institute for Health and Care Excellence. Intermediate Care Including Reablement (NG74). 2017. Available online: https://www.nice.org.uk/guidance/ng74/evidence/full-guideline-pdf-4600707949 (accessed on 20 December 2018).

16. Beecroft, C.; Booth, A.; Rees, A. The Research Process in Nursing, 7th ed.; Gerrish, K., Lathlean, J., Eds.; Wiley Blackwell: Hoboken, NJ, USA, 2016.

17. Moher, D.; Liberati, A.; Tetzlaff, J.; Altman, D.G. Preferred reporting items for systematic reviews and meta-analyses: The PRISMA statement. Br. Med. J. 2009, 8, 336-341. Available online: https://www.bmj.com/ content/339/bmj.b2535.full?view=long\&pmid=19622551 (accessed on 25 March 2019).

18. Ellis, P. Evidence-Based Practice in Nursing, 3rd ed.; SAGE Publications: Thousand Oaks, CA, USA, 2016.

19. The Kings Fund. Community Health Services Explained. 2019. Available online: https://www.kingsfund. org.uk/publications/community-health-services-explained\#comments-top (accessed on 20 March 2019).

20. Andrews, J.; Manthorpe, J.; Watson, R. Involving older people in intermediate care. J. Adv. Nurs. 2004, 46, 303-310. [CrossRef] [PubMed]

21. National Audit of Intermediate Care Summary Report-England. Assessing Progress in Services Aimed at Maximising Independence and Reducing use of Hospitals. 2017. Available online: https://s3.eu-west-2.amazonaws.com/nhsbn-static/NAIC\%20(Providers)/2017/NAIC\%20England\% 20Summary\%20Report\%20-\%20upload\%202.pdf (accessed on 20 March 2019).

22. Critical Appraisal Skills Programme. CASP (Qualitative) Checklist. 2018. Available online: https: //casp-uk.net/casp-tools-checklists/ (accessed on 2 March 2019).

23. Birkeland, A.; Tuntland, H.; Forland, O.; Jakobsen, F.F.; Langeland, E. Interdisciplinary collaboration in reablement-A qualitative study. J. Multidiscip. Healthc. 2017, 10, 195-203. [CrossRef] [PubMed]

24. Hjelle, K.M.; Tuntland, H.; Forland, O.; Alvsvag, H. Driving forces for home-based reablement; a qualitative study of older adults' experiences. Health Soc. Care Commun. 2017, 25, 1581-1589. [CrossRef] [PubMed]

25. Hjelle, K.M.; Skutle, O.; Forland, O.; Alvsvag, H. The reablement team's voice: A qualitative study of how an integrated multidisciplinary team experiences participation in reablement. J. Multidiscip. Healthc. 2016, 9, 575-585. [CrossRef] [PubMed]

26. Jokstad, K.; Skovdahl, K.; Landmark, B.T.H.; Haukelien, H. Ideal and reality; Community healthcare professionals' experiences of user-involvement in reablement. Health Soc. Care Commun. 2019, 27, 907-916. [CrossRef] [PubMed]

27. Moe, A.; Brataas, H.V. Patient influence in home-based reablement for older persons: Qualitative research. BMC Health Serv. Res. 2017, 17, 736. Available online: https://bmchealthservres.biomedcentral.com/track/ pdf/10.1186/s12913-017-2715-0 (accessed on 9 February 2019). [CrossRef] [PubMed]

28. Rose, A.; Rosewilliam, S.; Soundy, A. Shared decision-making within goal-setting in rehabilitation: A mixed-methods study. Clin. Rehabil. 2019, 33, 564-574. [CrossRef] [PubMed]

29. Wilde, A.; Glendinning, C. 'If they're helping me then how can I be independent?' The perceptions and experience of users of home-care re-ablement services. Health Soc. Care Commun. 2012, 20, 583-590.

30. Randstrom, K.B.; Wengler, Y.; Asplund, K.; Svedlund, M. Working with ‘hands off' support: A qualitative study of multidisciplinary teams' experiences of home rehabilitation for older people. Int. J. Old. People Nurs. 2014, 9, 25-33. [CrossRef] [PubMed]

31. Ali, M. Communication skills 1: Benefits of effective communication for patients. Nurs. Times 2017, 113, 18-19. Available online: https://www.nursingtimes.net/clinical-archive/assessment-skills/communicationskills-1-benefits-of-effective-communication-for-patients/7022148.article (accessed on 21 April 2019).

32. Nursing \& Midwifery Council. The Code Professional Standards of Practice and Behaviour for Nurses, Midwives and Nursing Associates. 2018. Available online: https:/www.nmc.org.uk/standards/code/ (accessed on 1 April 2019).

33. Miller, L. Effective communication with older people. Nurs. Stand. 2002, 17, 45-50. [CrossRef] [PubMed]

34. Moran, A.; Nancarrow, S.A.; Enderby, P. Mechanisms to enhance the effectiveness of allied health and social care assistants in community-based rehabilitation services: A qualitative study. Health Soc. Care Commun. 2015, 23, 389-398. [CrossRef] [PubMed] 
35. Angel, S.; Frederiksen, K.N. Challenges in achieving patient participation: A review of how patient participation is addressed in empirical studies. Int. J. Nurs. Stud. 2015, 52, 1525-1538. [CrossRef] [PubMed]

36. National Institute for Health and Care Excellence. Patient Experience in Adult NHS Services: Improving the Experience of Care for People Using Adult NHS Services (CG138). 2012. Available online: https://www.nice. org.uk/guidance/cg138/chapter/1-Guidance\#enabling-patients-to-actively-participate-in-their-care (accessed on 22 January 2019).

(c) (4)

(C) 2020 by the authors. Licensee MDPI, Basel, Switzerland. This article is an open access article distributed under the terms and conditions of the Creative Commons Attribution (CC BY) license (http://creativecommons.org/licenses/by/4.0/). 